

\title{
Relevance of a combined process coupling electro-Fenton and biological treatment for the remediation of sulfamethazine solutions - Application to an industrial pharmaceutical effluent
}

Dorsaf Mansour, Florence Fourcade, Isabelle Soutrel, Didier Hauchard, Nizar

Bellakhal, Abdeltif Amrane

\section{To cite this version:}

Dorsaf Mansour, Florence Fourcade, Isabelle Soutrel, Didier Hauchard, Nizar Bellakhal, et al.. Relevance of a combined process coupling electro-Fenton and biological treatment for the remediation of sulfamethazine solutions - Application to an industrial pharmaceutical effluent. Comptes Rendus. Chimie, 2015, 18 (1), pp.39-44. 10.1016/j.crci.2014.05.005 . hal-01101469

HAL Id: hal-01101469

https://hal-univ-rennes1.archives-ouvertes.fr/hal-01101469

Submitted on 8 Jan 2015

HAL is a multi-disciplinary open access archive for the deposit and dissemination of scientific research documents, whether they are published or not. The documents may come from teaching and research institutions in France or abroad, or from public or private research centers.
L'archive ouverte pluridisciplinaire HAL, est destinée au dépôt et à la diffusion de documents scientifiques de niveau recherche, publiés ou non, émanant des établissements d'enseignement et de recherche français ou étrangers, des laboratoires publics ou privés. 
Relevance of a combined process coupling electro-Fenton and biological treatment for the remediation of sulfamethazine solutions - Application to an industrial pharmaceutical effluent

Dorsaf Mansour ${ }^{\mathrm{a}, \mathrm{c}, \mathrm{d}}$, Florence Fourcade ${ }^{\mathrm{a}, \mathrm{d}}$, Isabelle Soutrel ${ }^{\mathrm{a}, \mathrm{d}}$, Didier Hauchard ${ }^{\mathrm{a}, \mathrm{d}}$, Nizar Bellakhal $^{\mathrm{c}}$, Abdeltif Amrane $\mathrm{a}^{\mathrm{a}, \mathrm{d}}$

${ }^{a}$ Université de Rennes 1, Ecole Nationale Supérieure de Chimie de Rennes, CNRS, UMR 6226, 11 allée de Beaulieu, CS 50837, 35708 Rennes Cedex 7, France

${ }^{\mathrm{c}}$ Laboratoire de recherche de Catalyse d'Electrochimie de Nanomatériaux et leurs applications et de didactique CENAD, Institut National des Sciences Appliquées et de Technologie (INSAT), B.P.Nº76, 1080 Tunis Cedex, Tunisia

${ }^{\mathrm{d} U n i v e r s i t e ́ ~ E u r o p e ́ e n n e ~ d e ~ B r e t a g n e, ~} 5$ boulevard Laënnec, 35000, France

*Corresponding author: Phone: (+33) 2232381 55; Fax: (+33) 2232381 20;

abdeltif.amrane@univ-rennes1.fr 


\section{Abstract}

A combined process coupling an electro-Fenton pretreatment and a biological degradation was implemented in order to mineralize synthetic and industrial pharmaceutical effluents, containing a veterinary antibiotic, sulfamethazine (SMT). The electro-Fenton pretreatment of SMT synthetic solution was first examined and the obtained results showed total SMT degradation after $30 \mathrm{~min}$ of electrolysis at $\mathrm{pH} 3,18^{\circ} \mathrm{C}, 500 \mathrm{~mA}$ and an initial SMT concentration of $0.2 \mathrm{mM}$, while the level of mineralization remained low $(2.1$ and $18.1 \%$ for 30 and 60 min electrolysis times), ensuring significant residual organic content for a subsequent biological treatment. In a second part, biological treatments were performed to complete the mineralization of the electrolyzed solutions of SMT, showing a significant level of mineralization after about 18 days of culture, $61.4 \%$ for 30 min pretreatment. The same electrolysis conditions were then applied to the pretreatment of an industrial pharmaceutical effluent, showing a total SMT removal in the effluent after 100 min of electrolysis, while mineralization yield remained also low $(7.5 \%)$, showing the formation of organic intermediate products. Fortunately, the mineralization yield during the subsequent biological treatment increased to almost $80 \%$, namely an overall yield of $81.4 \%$. Consequently, the integrated electro-Fenton-biological treatment process proved to be an efficient technology to remediate industrial pharmaceutical effluents.

Keywords: Sulfamethazine; Combined processes; Electro-Fenton; Activated sludge culture; Pharmaceutical effluents.

\section{Introduction}

The occurrence of human and veterinary pharmaceuticals in different water bodies worldwide becomes recently a serious environmental problem [1]. These compounds cannot be treated 
by wastewater treatment plants, resulting in their persistence and accumulation to measurable levels in aquatic ecosystems $[2,3]$. Over the last decade, a large variety of physical, chemical and biological technologies were used for wastewater treatment [4,5], but did not appear to be enough effective when dealing with wastes containing antibiotics, owing to the important recalcitrance of these compounds. Therefore, the development of efficient treatment methods to mineralize antibiotics before their disposal in the environment is needed.

Advanced oxidation processes (AOPs) are potentially powerful methods, based on the generation of hydroxyl radicals $\left({ }^{\circ} \mathrm{OH}\right)$ which are very reactive and non-selective oxidizing agents, leading to the degradation of organic pollutants by hydrogen atom abstraction reaction, electron transfer, or electrophilic addition to $\pi$ systems [6-10]. These processes involve chemical, photochemical or electro-chemical techniques such as Fenton, UV/ or $\mathrm{H}_{2} \mathrm{O}_{2}$ / ozonation, photo-Fenton, heterogeneous photocatalysis and electro-Fenton [9-13].

Electro-Fenton is an electrochemical advanced oxidation process based on the continuous generation of $\mathrm{H}_{2} \mathrm{O}_{2}$ in an acidic medium through the electrochemical reduction of $\mathrm{O}_{2}$ at the cathode (equation 1). The generated $\mathrm{H}_{2} \mathrm{O}_{2}$ reacts with the added $\mathrm{Fe}^{2+}$ ions to produce hydroxyl radicals $\left({ }^{\circ} \mathrm{OH}\right)$ and $\mathrm{Fe}^{3+}$ ions via the Fenton's reaction (equation 2), which is favored by the catalytic action of the $\mathrm{Fe}^{3+} / \mathrm{Fe}^{2+}$ system, mainly from the regeneration of $\mathrm{Fe}^{2+}$ by the cathodic reduction of $\mathrm{Fe}^{3+}$ (equation 3) $[6,9,11,14]$. Moreover, the method and the involved reactor are easy to handle and to use.

$$
\begin{aligned}
& \mathrm{O}_{2}+2 \mathrm{e}^{-}+2 \mathrm{H}^{+} \rightarrow \mathrm{H}_{2} \mathrm{O}_{2} \quad\left(\mathrm{E}^{\circ}=0.69 \mathrm{~V} / \mathrm{SHE}\right) \\
& \mathrm{Fe}^{2+}+\mathrm{H}_{2} \mathrm{O}_{2} \rightarrow \mathrm{Fe}^{3+}+\mathrm{OH}^{-}+{ }^{\circ} \mathrm{OH} \quad(\text { Fenton's reaction }) \\
& \mathrm{Fe}^{3+}+\mathrm{e}^{-} \rightarrow \mathrm{Fe}^{2+} \quad\left(\mathrm{E}^{\circ}=0.77 \mathrm{~V} / \mathrm{SHE}\right)
\end{aligned}
$$

However, electro-Fenton oxidation for complete mineralization requires generally a long time and can be then expensive, because by-products generated during electrolysis may be more 
resistant to their degradation and compete with the target compound degradation. In this case, one alternative is to apply this electro-chemical method as a pre-treatment step, in order to convert the initial persistent compound into more biodegradable intermediates, which would then be treated in a biological degradation process with the aim of reducing costs [15].

Sulfamethazine (STM) is an antibiotic that belongs to the pharmaceutically important group of heterocyclic sulfonamides. It is widely used in medicine and veterinary practice as antibacterial drug in pharmaceutical preparations [16]. Degradation of sulfamethazine has been examined through various methods. These studies mainly deal with Advanced Oxidation Processes, such as photo-Fenton [17] and photo-catalysis with $\mathrm{TiO}_{2}$ and $\mathrm{ZnO}$ as catalysts [16]. Among AOP, the relevance of Electrochemical Advanced Oxidation Processes (EAOP) for the pretreatment of synthetic sulmathezine solutions was also recently shown [18].

The purpose of this study was therefore to complete these previous works and hence to confirm the relevance of such combined process for the mineralization of a synthetic solution of a veterinary antibiotic, sulfamethazine, and its implementation to an industrial pharmaceutical effluent containing this antibiotic.

\section{Materials and Methods}

\subsection{Chemicals}

Sufamethazine (99\%) and acetonitrile (purity 99.9\%) (HPLC grade) were purchased from Sigma Aldrich (Saint Quentin Fallavier, France). $\mathrm{FeSO}_{4} .7 \mathrm{H}_{2} \mathrm{O}$ (purity 99\%) and $\mathrm{Na}_{2} \mathrm{SO}_{4}$ (purity 99\%) used as a catalyst source and inert supporting electrolyte respectively, were provided from Acros Organics (Thermo Fisher Scientific, Illkirch, France). All solutions were prepared in ultra-pure water and all the other chemicals used for analysis were purchased from Acros Organics and Sigma Aldrich. 


\subsection{Characterization of the pharmaceutical effluent}

The effluent used in this study was supplied by a pharmaceutical industry located in north Tunisia, collected in a closed container and stored in obscurity at $4{ }^{\circ} \mathrm{C}$. Before treatment, the effluent was diluted to obtain an initial SMT concentration of $0.2 \mathrm{mM}$, in order to conduct the treatment in the same conditions as the synthetic solution. The main characteristics of this pharmaceutical effluent were collected in Table 1.

\subsection{Analytical determinations}

\subsubsection{High Performance Liquid Chromatography (HPLC)}

The evolution of sulfamethazine concentrations was monitored by HPLC using a Waters 996 system equipped with Waters 996 PDA (Photodiode Array Detector) and Waters 600LCD Pump. The separation was achieved on a Waters $\mathrm{C}_{18},(5 \mu \mathrm{m} ; 4.6 \times 250 \mathrm{~mm})$ reversed-phase column. The eluent consisted of a mixture of acetonitrile/water (35/65 v/v with synthetic solution and 20/80 v/v with pharmaceutical effluent) delivered at a flow rate of $1 \mathrm{~mL} \mathrm{~min}{ }^{-1}$. Detection of sulfamethazine was carried out at $268 \mathrm{~nm}$.

\subsubsection{Chemical Oxygen Demand (COD) measurements}

Chemical Oxygen Demand (COD) was measured by means of Nanocolor ${ }^{\circledR}$ tests CSB 160 and 1500 from Macherey-Nagel (Düren, Germany). The amount of oxygen required for the oxidation of the organic and mineral matter at $148{ }^{\circ} \mathrm{C}$ for $2 \mathrm{~h}$ was quantified after oxidation with $\mathrm{K}_{2} \mathrm{Cr}_{2} \mathrm{O}_{7}$ at acidic $\mathrm{pH}[19]$.

\subsubsection{Total Organic Carbon (TOC) measurements}

The solutions were filtered on Sartorius Stedim Minisart $0.40 \mu \mathrm{m}$ GF prefilters (Goettingen, Germany). TOC was measured by means of a TOC- $\mathrm{V}_{\mathrm{CPH} / \mathrm{CPN}}$ Total Organic Analyzer 
Shimadzu. Organic carbon compounds were combusted and converted to $\mathrm{CO}_{2}$, which was detected and measured by a non-dispersive infrared detector (NDIR). Reproducible TOC values were always obtained using the standard NPOC (Non Purgeable Organic Carbon) method. For each sample, each measurement was triplicated [15].

\subsubsection{Activated Sludge Preparation}

Activated Sludge used in this study was collected from a local wastewater treatment plant (Rennes Beaurade, Bretagne, France). Before use and to avoid any residual carbon or mineral nutrient, it was treated as previously detailed [20].

\subsubsection{Biological Oxygen Demand (BOD $)_{5}$ measurements}

$\mathrm{BOD}_{5}$ measurements were carried out in Oxitop IS6 (WTW, Alès, France). Activated sludge provided by a local wastewater treatment plant (Rennes Beaurade, Bretagne, France) was used to inoculate duplicate flasks and the initial microbial concentration was set to $0.05 \mathrm{~g} \mathrm{~L}^{-1}$. More details regarding the experimental procedure can be found in a previous paper [18].

\subsection{Experimental Procedure}

\subsubsection{Electro-Fenton process}

The degradation of the organic matter by the electro-Fenton process was carried out in a $1 \mathrm{~L}$ undivided cylindrical glass cell equipped with two electrodes, a carbon felt piece placed on the inner wall of the cell (Mersen RVG 4000, Paris La Défense, France) and was used as the cathode a cylindrical platinum electrode used as the anode located in the center of the electrochemical reactor to have a good potential distribution. Prior to electrolysis, compressed air was bubbled for $10 \mathrm{~min}$ through the solution to saturate the aqueous solution [20]. 
The $\mathrm{pH}$ of the solutions was adjusted to 3 by sulfuric acid $\left(\mathrm{H}_{2} \mathrm{SO}_{4}\right)$. A catalytic quantity of $\mathrm{FeSO}_{4} .7 \mathrm{H}_{2} \mathrm{O}(0.5 \mathrm{mM})$ was introduced into the cell just before electrolysis. The electrodes were connected to a DC power supply (Metrix, model AX 322, Chauvin Arnoux Group, Paris, France) operating in galvanostatic mode to control the current intensity at a value of $500 \mathrm{~mA}$. The ionic strength was maintained constant by the addition of $0.05 \mathrm{M} \mathrm{Na}_{2} \mathrm{SO}_{4}$ as supporting electrolyte. The electrolytic solution was in circulation with the help of a peristaltic pump (flow rate of $2 \mathrm{~L} \mathrm{~min}^{-1}$ ). The temperature was maintained at $18^{\circ} \mathrm{C}$ and the initial sulfamethazine concentration was $0.2 \mathrm{mM}$, for pure SMT solution and after appropriate dilution of the industrial effluent to achieve this concentration.

\subsubsection{Biological treatment}

Culture media were prepared in duplicate in $500 \mathrm{~mL}$ serum bottles containing $200 \mathrm{~mL}$ of the sulfamethazine synthetic solutions or the pharmaceutical effluent, beforehand pretreated by the electro-Fenton process. The initial composition $\left(\mathrm{mg} \mathrm{L}^{-1}\right)$ of the mineral solution was: $\mathrm{Na}_{2} \mathrm{HPO}_{4}, 334 ; \mathrm{K}_{2} \mathrm{HPO}_{4}, 208 ; \mathrm{KH}_{2} \mathrm{PO}_{4}, 85 ; \mathrm{CaCl}_{2}, 27.4 ; \mathrm{MgSO}_{4} .7 \mathrm{H}_{2} \mathrm{O}, 22.6 ; \mathrm{NH}_{4} \mathrm{Cl}, 2$; $\mathrm{FeCl}_{3} .6 \mathrm{H}_{2} \mathrm{O}, 0.26$; and the initial $\mathrm{pH}$ was adjusted to 7 . Activated sludge was added in order to have initial concentration of $1 \mathrm{~g} \mathrm{~L}^{-1}$ of dry matter. Cultures were agitated at room temperature $\left(25^{\circ} \mathrm{C}\right)$ and $5 \mathrm{~mL}$ samples were taken regularly, filtered through $0.45 \mu \mathrm{m}$-syringe filters and injected for TOC measurements.

\section{Results and Discussion}

\subsection{Pretreatment of SMT by the electro-Fenton process}

The degradation of sulfamethazine by the electro-Fenton process using a carbon felt cathode and a platinum anode has been previously studied under various experimental conditions including current intensity, temperature and initial sulfamethazine concentration [18]. The 
corresponding results showed that an initial SMT concentration of $0.2 \mathrm{mM}$ appeared to be a good compromise between the initial concentration level and the degradation yield, an increase of the temperature above $18^{\circ} \mathrm{C}$ appeared not really relevant with respect to the increase of the operating costs while the increase of the degradation yield remained limited. The optimal initial ferrous concentration and current intensity appeared to be $0.5 \mathrm{mM}$ and 500 $\mathrm{mA}$, respectively. These optimal conditions led to a rapid degradation until $100 \%$ of elimination after 30 min pretreatment (Fig.1a); while mineralization remained limited, 2.1 and $18.1 \%$ for 30 and 60 min electrolysis times (Fig.1a), as well as rather low levels of oxidation (28.4 and 55.6\% from an initial amount of $88 \mathrm{mg} \mathrm{L}^{-1} \mathrm{O}_{2}$ after 30 and 60 min pretreatment respectively) (Fig.1b), which suggested the formation of organic intermediate products, as confirmed at the examination of the HPLC profiles [20], showing that the disappearance of SMT was accompanied by the formation of several intermediate products, due to the oxidation of the generated products by hydroxyl radicals [21].

\subsection{The Biodegradability of SMT}

In order to follow the evolution of the biodegradability profile during the electro-Fenton pretreatment, the samples were analyzed for $\mathrm{BOD}_{5}$ and $\mathrm{COD}$. As can be seen, the measurement of the biodegradability of the target molecule led to a value of 0.17 for the $\mathrm{BOD}_{5} / \mathrm{COD}$ ratio (Fig.1b), confirming the recalcitrance of SMT and the need for its oxidation prior to a biological treatment; while the ratio increased to 0.31 and 0.51 for 30 and 60 min electrolysis times (Fig.1b), namely above the limit of biodegradability after only $1 \mathrm{~h}$ pretreatment [22]. 


\subsection{Biodegradation of the electrolyzed solution of SMT}

Owing to biodegradability improvement, activated sludge cultures were carried out on an SMT solution pretreated during the time needed for its total degradation, namely $30 \mathrm{~min}$ (Fig.2). It should be remembered that in the absence of pretreatment the SMT recalcitrance was previously confirmed since no degradation was observed even after 20 days activated sludge culture [20]. Regarding the pretreated SMT solution, almost constant TOC values were observed until nearly the 10th day of culture, showing obviously an absence of possible biosorption of the degradation products (Fig.2). Then mineralization yield increased significantly until reaching $61.4 \%$ on the 18 th day of culture. It can be assumed that at the beginning of culture, microorganisms were not able to assimilate the by-products generated during the degradation of SMT by the electro-Fenton process. The mineralization observed from the 10th day of culture was most likely characteristic of the acclimation of activated sludge to the degradation products, in agreement with previous results recorded during the treatment of a pesticide, phosmet, by means of a combined process coupling an electrochemical pretreatment with a biological treatment [22]. The overall mineralization efficiency of the combined process was therefore $62.2 \%$ for the SMT solution pretreated during $30 \mathrm{~min}$, of which $2.1 \%$ corresponded to the electro-Fenton pretreatment and $61.4 \%$ to the biological treatment.

\subsection{Application to an industrial pharmaceutical effluent}

The optimal conditions determined previously for the SMT degradation by electro-Fenton process $\left(0.2 \mathrm{mM} \mathrm{SMT}, 0.5 \mathrm{mM} \mathrm{Fe}{ }^{2+}, 500 \mathrm{~mA}\right.$ and $\left.18^{\circ} \mathrm{C}\right)$ were applied to an industrial pharmaceutical effluent (Fig.1c) and showed that nearly 100 min were needed for total SMT removal. Besides, a slower SMT degradation can be noticed in the industrial effluent if compared to the synthetic solution, while the initial SMT amount was the same in both 
solutions; this behavior might be attributed to the competitive consumption of hydroxyl radicals by other organic compounds contained in the real effluent. A low level of mineralization was concomitantly observed $(7.5 \%$ - Fig.1c), as well as a relatively low level of oxidation (28.9\% from an initial amount of $566 \mathrm{mg} \mathrm{L}^{-1} \mathrm{O}_{2}$ ) (Fig.1d), this result can be explained by the generation of intermediate compounds simultaneously with the degradation of the target compound, as confirmed at the examination of the HPLC profiles (data not shown). On the other hand, the industrial effluent showed a low $\mathrm{BOD}_{5} / \mathrm{COD}$ ratio $(0.17)$ (Fig.1d), indicating low biodegradability and similar to that obtained for synthetic SMT solution, confirming the need for pretreatment prior to biological treatment. Indeed, the SMT represented roughly $15 \%$ of the COD and COT in the real effluent. Even if other organic compounds were present in significant amount in the effluent, the biodegradability value (0.17) similar to that obtained for the synthetic SMT solution seemed to indicate that effluent recalcitrance should be related to the presence of SMT.

Prior to the biological treatment step, possible biosorption on activated sludge of the organic content of the industrial effluent was assessed. $250 \mathrm{~mL}$ Erlenmeyer flasks containing $100 \mathrm{~mL}$ of medium were inoculated with $0.5 \mathrm{~g} \mathrm{~L}^{-1}$ of activated sludge, which was washed in the same conditions as the biological treatment. The flasks were stirred at $250 \mathrm{rpm}$ and the experiments were triplicated to ensure the reproducibility of the results. Samples were regularly taken over a $5 \mathrm{~h}$ period, filtered on $0.45 \mu \mathrm{m}$ and then analyzed by TOC measurements. As displayed in Fig.3, no significant TOC decrease was detected within $5 \mathrm{~h}$ experiment, showing the absence of organic material biosorption. Indeed, since biosorption is a rapid phenomenon, it would have been noticed within $5 \mathrm{~h}$.

After 100 min electro-Fenton oxidation, the $\mathrm{BOD}_{5} / \mathrm{COD}$ ratio increased to 0.32 , showing pretreatment efficiency; therefore and even if the limit of biodegradability (0.4) was not reached, activated sludge culture was carried out for 15 days on the pretreated effluent, since 
SMT recalcitrance was clearly shown and hence the positive impact of electro-Fenton pretreatment [20]. In view of comparison with the synthetic effluent, 100 min pretreatment time was chosen, since it corresponded to a total SMT degradation.

High levels of mineralization were observed during the first days of culture until reaching $76.8 \%$ within about 8 days for the non-pretreated industrial effluent and after electrolysis respectively, showing the impact of the pretreatment and confirming that effluent biorecalcitrance was related to the presence of SMT instead of the organic compounds present in the effluent. This behavior can be attributed to a readily assimilation of some of the degradation products by microorganisms [23]. No further significant mineralization was observed between day 8 and day 15; mineralization yield increased only slightly to reach $79.9 \%$ on the $15^{\text {th }}$ day of biological treatment.

It should be noticed that the differences in the observed trends between the synthetic solution and the industrial effluent were not in disagreement with the similar $\mathrm{BOD}_{5}$ on $\mathrm{COD}$ ratio obtained for both solution, 0.17 , owing to the difference in the initial amounts of activated sludge inoculated, $1 \mathrm{~g} \mathrm{~L}^{-1}$ for the biological treatment and $0.05 \mathrm{~g} \mathrm{~L}^{-1}$ for $\mathrm{BOD}_{5}$ experiments. A higher level of mineralization was obtained during the biological treatment of the pretreated industrial effluent if compared to that of the pretreated synthetic solution, 79.9 and $61.4 \%$ after 15 and 18 days respectively (Fig.2), which should also be related to the organic content of the industrial effluent apart of SMT.

From this, the overall mineralization efficiency of the combined process achieved a value of $81.4 \%$ for the industrial pharmaceutical effluent pretreated during $100 \mathrm{~min}$, of which $7.5 \%$ corresponded to the electro-Fenton pretreatment and $79.9 \%$ to the biological treatment.

The results dealing with the industrial effluent suggested therefore a more complex strategy to achieve total effluent mineralization. For this purpose, a final electro-Fenton treatment of the 
biologically treated solution could be considered. The corresponding work is in progress in the laboratory.

\section{Conclusion}

The relevance of the coupling of electro-Fenton pretreatment with a biological treatment for the elimination of a veterinary antibiotic, sulfamethazine (SMT), from aqueous medium was investigated. Pretreatment was carried out under the best operating conditions, namely an initial SMT concentration of $0.2 \mathrm{mM}$, a ferrous ions concentration of $0.5 \mathrm{mM}$, at $\mathrm{pH} 3,18^{\circ} \mathrm{C}$ and $500 \mathrm{~mA}$ current intensity. Despite a total SMT degradation obtained after only 30 minutes of electrolysis, the low levels of oxidation and mineralization, $28.4 \%$ for the former and $2.1 \%$ for the latter after $30 \mathrm{~min}$ electrolysis, indicated the formation of organic intermediate products. However, after subsequent biological treatment a mineralization yield of $61.4 \%$ was obtained for the pretreated solution.

In a second step, an industrial effluent, supplied by a pharmaceutical industry located in north Tunisia, was pretreated under the same operating conditions, showing a total SMT degradation after 100 min of oxidation, while mineralization remained limited (7.5\%). During the subsequent biological treatment, TOC removal increased significantly, to reach $79.9 \%$ on the $15^{\text {th }}$ day, which lead to an overall mineralization efficiency of the combined process of $81.4 \%$, confirming its relevance, even for the treatment of industrial effluents. 


\section{References}

[1] Z. Dong, D.B. Senn, R.E. Moran, J.P. Shine, Regul. Toxicol. Pharmacol. 65 (2013) 60.

[2] A.L. Batt, I.B. Bruce, D.S. Aga, Environ. Pollut. 142 (2006) 295.

[3] J.R. Domínguez, T. González, P. Palo, E.M. Cuerda-Correa, Desalination 269 (2011) 231.

[4] M.L. Daumer, F. Béline, F. Guiziou, M. Sperandio, Biosystems Eng. 96 (2007) 379.

[5] T. Vroumsia, R. Steiman, F. Seigle-Murandi, J.L. Benoit-Guyod, A. Khadrani, Chemosphere 33 (1996) 2045.

[6] E. Brillas, I. Sirés, M.A. Oturan, Chem. Rev. 109 (2009) 6570.

[7] M.M. Ghoneim, H.S. El-Desoky, N.M. Zidan, Desalination 274 (2011) 22.

[8] M.A. Oturan, J. Appl. Electrochem. 30 (2000) 475.

[9] M.A. Oturan, N. Oturan, M.C. Edelahi, F.I. Podvorica, K.E. Kacemi, Chem. Eng. J. 171 (2011) 127.

[10] A. Özcan, Y. Şahin, M.A. Oturan, Water Res. 47 (2013) 1470.

[11] S. Loaiza-Ambuludi, M. Panizza, N. Oturan, A. Özcan, M.A. Oturan, J. Electroanal. Chem. 702 (2013) 31.

[12] H.Y. Shu, M.C. Chang, Dyes Pigment. 65 (2005) 25.

[13] H. Yang, T. An, G. Li, W. Song, W.J. Cooper, H. Luo, X. Guo, J. Hazard. Mater. 179 (2010) 834.

[14] S. Garcia-Segura, J.A. Garrido, R.M. Rodriguez, P.L. Cabot, F. Centellas, C. Arias, E. Brillas, Water Res. 46 (2012) 2067.

[15] I. Oller, S. Malato, J.A. Sánchez-Pérez, Sci. Total Environ. 409 (2011) 4141.

[16] S. Kaniou, K. Pitarakis, I. Barlagianni, I. Poulios, Chemosphere 60 (2005) 372. 
[17] M. Perez-Moya, M. Graells, G. Castells, J. Amigo, E. Ortega, G. Buhigas, L.M. Pérez, H.D. Mansilla, Water Res. 44 (2010) 2533.

[18] D. Mansour, F. Fourcade, N. Bellakhal, M. Dachraoui, D. Hauchard, A. Amrane, Water Air Soil Pollut. 223 (2012) 2023.

[19] F. Fourcade, S. Yahiat, K. Elandaloussi, S. Brosillon, A. Amrane, Chem. Eng. Technol. 35 (2012) 238.

[20] D. Mansour, F. Fourcade, S. Huguet, I. Soutrel, N. Bellakhal, M. Dachraoui, D. Hauchard, A. Amrane, Int. Biodeterior. Biodegrad. 88 (2014) 29.

[21] S. Hammami, N. Bellakhal, N. Oturan, M.A. Oturan, M. Dachraoui, Chemosphere 73 (2008) 678.

[22] N.A. Salles, F. Fourcade, F. Geneste, D. Floner, A. Amrane, J. Hazard. Mater. 181 (2010) 617.

[23] J.M. Fontmorin, S. Huguet, F. Fourcade, F. Geneste, D. Floner, A. Amrane, Biochem. Eng. J. 70 (2013) 17. 
Table 1. Main characteristics of pharmaceutical effluent

\begin{tabular}{ccccc}
\hline & $\begin{array}{c}\text { [SMT] } \\
\left(\mathrm{g} \mathrm{L}^{-1}\right)\end{array}$ & $\begin{array}{c}\text { Conductivity } \\
\left(\mathrm{mS} \mathrm{cm}^{-1}\right)\end{array}$ & $\begin{array}{c}\text { TOC } \\
\left(\mathrm{mg} \mathrm{L}^{-1}\right)\end{array}$ & $\left(\mathrm{mg} \mathrm{L}^{-1}\right)$ \\
\hline $\begin{array}{c}\text { Pharmaceutical } \\
\text { effluent }\end{array}$ & 1.2 & 1.2 & 11320 & 3774 \\
\hline
\end{tabular}

Table 2. TOC removal by combined electro-Fenton and biological treatment

\begin{tabular}{|c|c|c|c|c|c|c|c|}
\hline & $\begin{array}{c}\text { Untreated } \\
\text { TOC }\end{array}$ & \multicolumn{3}{|c|}{ Electro-Fenton pretreatment } & \multicolumn{2}{|c|}{ Biological treatment } & \multirow{2}{*}{$\begin{array}{c}\text { Total } \\
\% \text { removal }\end{array}$} \\
\hline & $\begin{array}{c}\text { TOC } \\
\left(\mathrm{mg} \mathrm{L}^{-1}\right)\end{array}$ & $\begin{array}{l}\text { Time } \\
(\min )\end{array}$ & $\begin{array}{c}\text { TOC } \\
\left(\mathrm{mg} \mathrm{L}^{-1}\right)\end{array}$ & $\begin{array}{c}\% \\
\text { Removal }\end{array}$ & $\begin{array}{c}\text { TOC } \\
\left(\mathrm{mg} \mathrm{L}^{-1}\right)\end{array}$ & $\begin{array}{c}\% \\
\text { Removal }\end{array}$ & \\
\hline SMT & 27.6 & 30 & 27.0 & 2.1 & 10.6 & 61.4 & 62.2 \\
\hline & 27.6 & 60 & 22.6 & 18.1 & 5.1 & 78.8 & 81.3 \\
\hline $\begin{array}{l}\text { Industrial } \\
\text { effluent }\end{array}$ & 188.7 & 100 & 174.4 & 7.5 & 21.5 & 79.9 & 81.4 \\
\hline
\end{tabular}


Figure captions
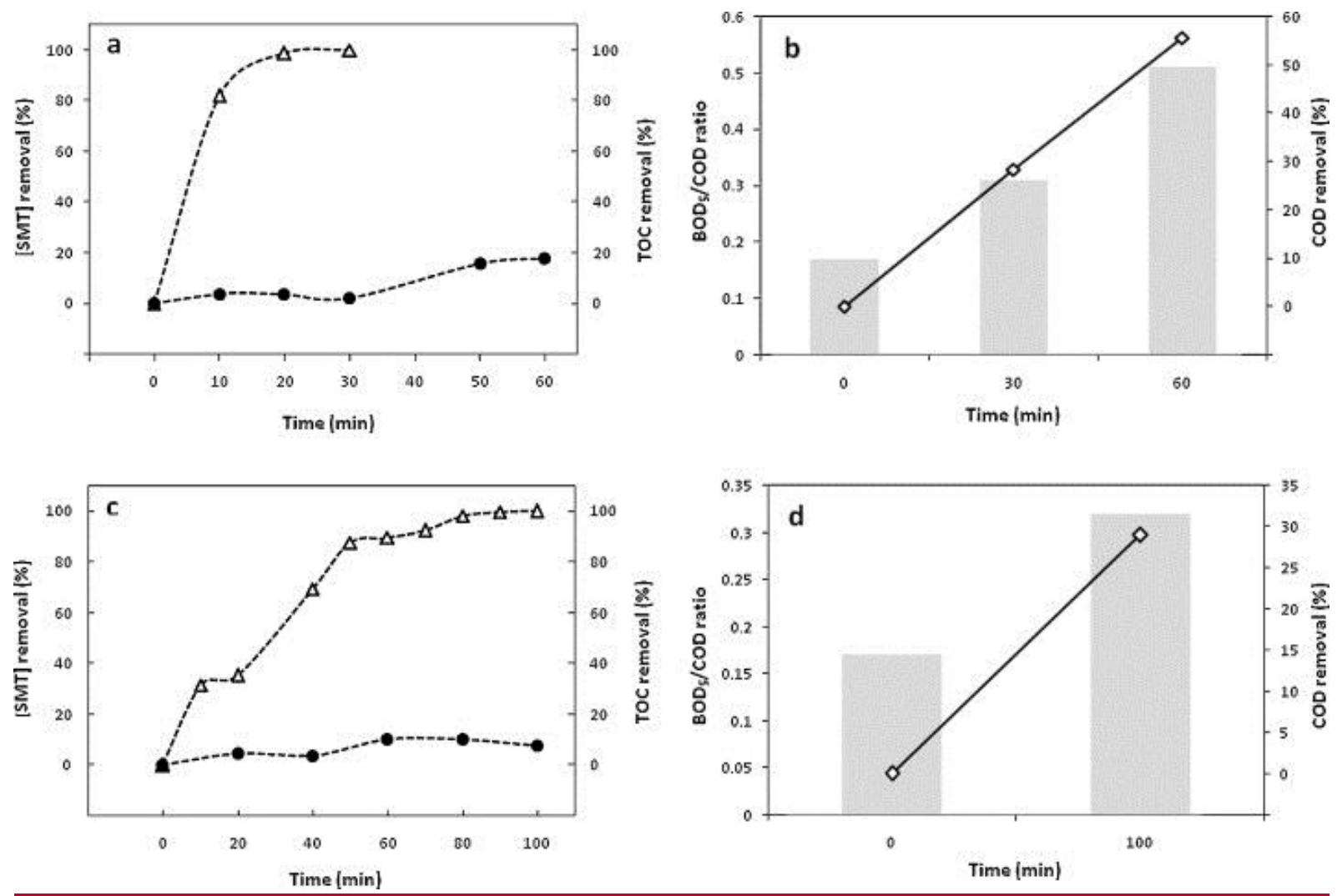

Fig. 1. Time evolution of SMT removal $(\Delta)$ and TOC removal $(\bullet)$ (a and c), BOD $/$ COD ratio (column bars) and COD removal $(\diamond)$ (b and d) during electro-Fenton pretreatment in the following experimental conditions: $\left[\mathrm{Fe}^{2+}\right]_{0}=0.5 \mathrm{mM},\left[\mathrm{Na}_{2} \mathrm{SO}_{4}\right]=50 \mathrm{mM}, \mathrm{pH}=3, \mathrm{~T}=18^{\circ} \mathrm{C}$, $\mathrm{I}=500 \mathrm{~mA}, \mathrm{~V}=1 \mathrm{~L}$ and $0.2 \mathrm{mM}$ was considered for the initial SMT concentration, for pure SMT solution and after appropriate dilution of the industrial effluent. 


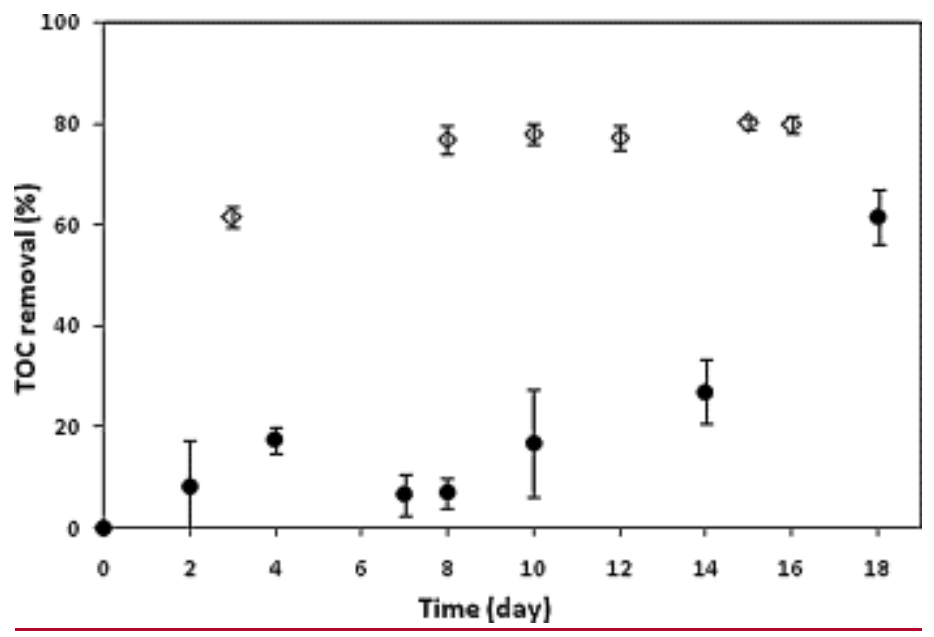

Fig. 2. Time-courses of activated sludge cultures of solutions of synthetic SMT solution pretreated during $30 \mathrm{~min}(\bullet)$ and industrial effluent pretreated during $100 \mathrm{~min}(\diamond)$. ElectroFenton pretreatment conditions: $\left[\mathrm{Fe}^{2+}\right]_{0}=0.5 \mathrm{mM},\left[\mathrm{Na}_{2} \mathrm{SO}_{4}\right]=50 \mathrm{mM}, \mathrm{pH}=3, \mathrm{~T}=18^{\circ} \mathrm{C}, \mathrm{I}=$ $500 \mathrm{~mA}, \mathrm{~V}=1 \mathrm{~L}$ and $0.2 \mathrm{mM}$ was considered for the initial SMT concentration, for pure SMT solution and after appropriate dilution of the industrial effluent.

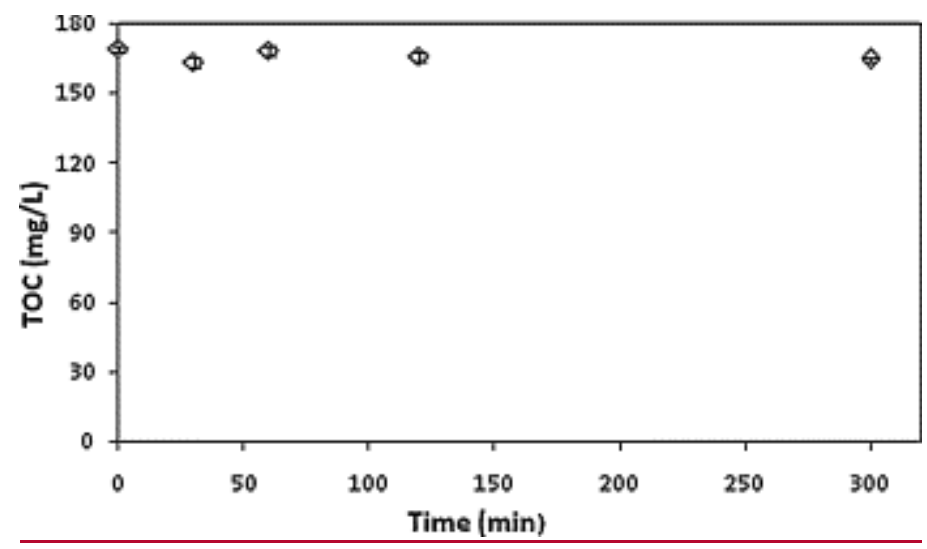

Fig. 3. Biosorption study of the organic content of the industrial effluent on activated sludge $\left(1 \mathrm{~g} \mathrm{~L}^{-1}\right)$. 